\title{
The first GM crop in Bangladesh - Bt Eggplant
}

\author{
AKM Quamruzzaman
}

\section{ABSTRACT}

Eggplant (Solanum melongena) commonly called Brinjal is the most popular vegetable in Bangladesh. It is extensively cultivated around homesteads and in commercial fields throughout the year. It is estimated that nearly 67 percent of the eggplant crop yield in Bangladesh is lost due to the damage caused by Leucinodes orbonalis also known as eggplant fruit and shoot borer (EFSB). EFSB is reportedly the most serious pest of eggplant. To overcome this EFSB problem Bt eggplant project has been initiated in 2004. The Agricultural Biotechnology Support Project II (ABSPII) is a USAIDsupported project that has funded the development of Bt eggplant in Bangladesh under the Public Private Partnership (PPP) mode. Bangladesh Agricultural Research Institute (BARI) received the Event EE-1 eggplant in Mahyco and backcrossed into nine popular eggplant varieties of Bangladesh selected based on the regional consumer preference. The efficacy of cry1Ac gene in providing effective resistance to the target pest was also assessed in terms of productively (fruit yield increase) which was studied in $9 \mathrm{Bt}$ eggplant lines for a period of 7 years from 2008 to 2015. To launch the best 4 varieties, BARI applied to the National Technical Committee on Crop Biotechnology (NTCCB). For release of GM crop variety, first of all follow the recommendation of NTCCB, then submitted to the National Technical Committee on Crop Biotechnology (NTCCB) Core Committee and then to the National Committee on Biosafety (NCB). The Bangladesh government approved four varieties namely, BARI Bt Begun-1 (Uttara), BARI Bt Begun2 (Kazla), BARI Bt Begun-3 (Nayantara) and BARI Bt Begun-4 (BARI Begun-6 or ISD006) on 30 October 2013 and these got momentum countrywide. On 22 January 2014, Bt seedlings were distributed among 20 farmers in four districts of Bangladesh as the first genetically modified (GM) crops. After the government of Bangladesh approved the cultivation of $\mathrm{Bt}$ eggplant in 2013, its popularity is increasing day by day and the socioeconomic condition of the farmers is also improving. Bt eggplant started its journey in 2014 with only 20 farmers, in seven years it has grown to about 27012 farmers and from 8 acres to about 5,000 acres. This advancement of Bt eggplant has also faced opposition from different quarters at different times. Today, the progress of Bt eggplant continues by overcoming all obstacles. Field days, trainings, various publications, documentary making, use of mass and social media, observations, workshops, stewardship activities are acting as important regulators of this progress.

Keywords: Eggplant, Bt Brinjal, genetically modified (GM) crops, eggplant fruit and shoot borer, EFSB, Leucinodes orbonalis, stewardship.
Submitted : February 04, 2021

Published : April 14, 2021

ISSN: $2684-1827$

DOI: $10.24018 /$ ejfood.2021.3.2.237

\section{AKM Quamruzzaman *}

Olericulture Division, Horticulture Research Center, Bangladesh Agricultural Research Institute, Bangladesh.

(e-mail: akmqzs@gmail.com)

\section{INTRODUCTION}

Solanum melongena L., popularly known as brinjal or eggplant or aubergine, belongs to the family Solanaceae is a widely grown vegetable in Asia, parts of Europe and Africa. The area under eggplant cultivation in Bangladesh is estimated at 52,396 ha with a total production of 5,30,610 MT, while the total vegetables production is about $43,71,878$ MT, that is, about $12.14 \%$ of the total production. In winter, different types of vegetables are cultivated, of which eggplant production is about 3,60,421 MT. On the other hand, in summer is about 1,70,189 MT [3]. Generally, height of eggplant plant is varied 40 to $150 \mathrm{~cm}$, leaves are large and coarsely lobed with 10 to $20 \mathrm{~cm}$ long and 5 to $10 \mathrm{~cm}$ broad. Semi wild types of plants may be much taller up to $225 \mathrm{~cm}$ along with large leaves (length $30 \mathrm{~cm} ; 15 \mathrm{~cm}$ diameter). The stem and leaves are sometime spiny. The flowers are bloom with white to purple color, with a five-lobed corolla and 5-6 yellow stamens [22].

Eggplant is a wide adapted crop, grown in different agroclimatic regions and can be cultivated throughout the year. Based on fruit colour, size and shape, there is a wide range of consumer preferences in the country; about 200 types of varieties/ genotypes of eggplant are cultivated in different parts of Bangladesh. There is a wide diversity among the eggplant cultivars in respect of fruit shapes, sizes, and colors [28]. Also, visible different types of shapes (egg to long clubshaped) and colors occurs from white, green, yellowish, purple and black color [53].

Eggplant the fruit is very nutritious and so many people are using eggplant for medicinal uses due to its high nutrition composition. Eggplant consists of a good amount of minerals 
viz., potassium, magnesium, sodium, calcium, iron, and phytochemicals that contain phenolic components (caffeine and chlorogenic acid), flavonoids, mainly nasunin [39] and dietary fiber that is helpful for our health [50] with very low amount of calories. Eggplant is ranked one of the most top ten vegetables which provide the healthiest food with high phenolic contents and minerals [11]. Secondary metabolites along with primary metabolites are producing by plants that contribute human health [33].

Due to indiscriminate insecticide sprays, farmers lose anywhere between 30 to $60 \%$ of the crop yield due to devastating EFSB pests and also suffer considerable expenses due to the high costs of the insecticides [4]. While farmers applied insecticides indiscriminately, several unwanted situations may arise like high pesticidal residue levels of fruit, kill beneficial insects and pollinators, hazards to workers and polluting the hazards environment happen [46]. To overcome this devastating insect, farmers have to spray broad-spectrum insecticides, even 2-3 times in a week. Consequently, more than 100 times sprays may be applied per season, resulting in high residues of insecticides on the edible fruit. Killing natural beneficial insects that can help reduce pest infestation, pollinators, mix-up of active pesticide ingredients into the soil and water, resulting the pollution. These types of problems have been seen in Bangladesh and the Philippines also [52].

\section{DISCUSSION}

Using genetic engineering different biotic and abiotic stress resistant biotech/ genetically modified crops are now being used for the human health and also to protect natural resources. Many countries are trying to solve the biotic and abiotic problem using biotechnology as conventional research methods often do not get the desired results and the benefits are already being obtained, as a result of which its demand has also increased day by day. Scientists use genetic engineering to transfer the desired the genes of one organism into another organism and invent new varieties with the desired characteristics.

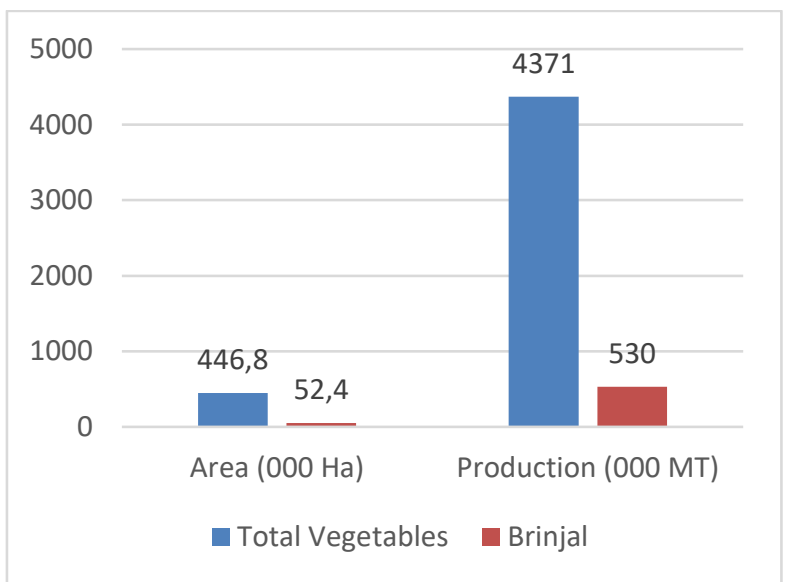

Fig. 1. Total production and area of total vegetables and brinjal in Bangladesh.

To judicious use of natural resources and to protect the human health, modern genetic engineering is widely used to develop more crop variety having tolerant to different biotic and abiotic stress and more nutritious. Each and every GM crop is evaluated and developed on a very systematic basis, while approved commercial products in the market have been subjected to rigorous scientific consideration. Genetically engineered crops are being widely used for improving crop yields as well as for more income for the farmers and has an unblemished record of food safety [25].

So far, no conventional breeding efforts of eggplant has been successful in development of insect resistant eggplant variety, that is resistant to EFSB. Cry1 Ac (Bt) protein produced by Bacillus thuringiensis, the naturally available soil bacteria have been reported to be most effective in controlling insect pests belonging to the group Lepidoptera. Leucinodes orbonalis also falls under this group. The history of safe use of Cry proteins in commercial crops has already been proved the world over by the introduction of Bt Corn, $\mathrm{Bt}$ Sweet Corn and Bt Cotton to control against lepidopteran insects. The biosafety and environmental safety of Cry genes of these genetically modified crops have been extensively studied across the world and are considered safe for human consumption and free from risks to animals and the environment.

To overcome the EFSB infestation, Cry1Ac gene containing Bt eggplant event EE-1 event has been developed by an Indian company named Mahyco and conducted considerable safety assessment in several accredited laboratories to ascertain the toxicity and allergenicity. All the biosafety studies carried out and reported have indicated that eggplant event EE-1 is safe for human consumption, as it displays no toxic effect or causes any allergenic response. Similarly, the Environmental Risk Assessment carried out for the Bt eggplant indicates that the product is safe for environmental release. The Indian regulatory authority (GEAC) has recommended the product safe for environmental release.

\section{A. World Scenario of Biotech Crops}

In the 23rd year of the utilization of genetically modified (GM) crops in 2018, 26 countries produced in 191.7 million hectares of GM crops. In 2018, the GM crop growing area was 75 million hectares by the USA, followed by Brazil, Argentina, Canada, and India (Table I) for a total of 174.5 million hectares, representing $91 \%$ of the global area. So, more than 1.95 billion people benefitted using crop biotechnology.

The fact that more than $90 \%$ are pest-resistant or herbicide-resistant biotech crops. These biotech crops continue to improve agricultural productivity and increase farmers' income prove that it affects this way. The effect of biotech crops as the technology has been proven and the technology has been gradually developed, the recent trend of biotech crop [27].

\section{B. Eggplant Fruit and Shoot Borer (EFSB)}

The major factor that adversely affects eggplant production is the Lepidoptera pest Leucinodes orbonalis eggplant fruit and shoot borer (EFSB). This is a tiny larva that bores into the petioles, midribs of leaves and shoots causing wilt of shoot tips and also bore the flower buds and tender fruits. In addition to a substantial reduction in crop yields, the resulting insects appear to be completely discarded or a massive reduction in market value. 
TABLE I: GLOBAL AREA OF BIOTECH CROPS IN 2018

\begin{tabular}{|c|c|c|c|}
\hline Rank & Country & $\begin{array}{c}\text { Area (Million } \\
\text { Hectares) }\end{array}$ & Biotech Crops \\
\hline 1 & USA* & 75.0 & $\begin{array}{l}\text { Maize, soybeans, cotton, canola, sugar beets, alfalfa, papaya, squash, potatoes, } \\
\text { apples }\end{array}$ \\
\hline 2 & Brazil* & 51.3 & Soybeans, maize, cotton, sugarcane \\
\hline 3 & Argentina* & 23.9 & Soybeans, maize, cotton \\
\hline 4 & Canada* & 12.7 & Canola, maize, soybeans, sugar beets, alfalfa, potatoes \\
\hline 5 & India* & 11.6 & Cotton \\
\hline 6 & Paraguay* & 3.8 & Soybeans, maize, cotton \\
\hline 7 & China* & 2.9 & Cotton, Papaya \\
\hline 8 & Pakistan* & 2.8 & Cotton \\
\hline 9 & South Africa* & 2.7 & Maize, soybeans, cotton \\
\hline 10 & Uruguay* & 1.3 & Soybeans, maize \\
\hline 11 & Bolivia* & 1.3 & Soybeans \\
\hline 12 & Australia* & 0.8 & Cotton, canola \\
\hline 13 & Philippines* & 0.6 & Maize \\
\hline 14 & Myanmar* & 0.3 & Cotton \\
\hline 15 & Sudan* & 0.2 & Cotton \\
\hline 16 & Mexico* & 0.2 & Cotton \\
\hline 17 & Spain* & 0.1 & Maize \\
\hline 18 & Colombia* & 0.1 & Cotton, maize \\
\hline 19 & Vietnam & $<0.1$ & Maize \\
\hline 20 & Honduras & $<0.1$ & Maize \\
\hline 21 & Chile & $<0.1$ & Maize, soybeans, canola \\
\hline 22 & Portugal & $<0.1$ & Maize \\
\hline 23 & Bangladesh & $<0.1$ & Brinjal/Eggplant \\
\hline 24 & Costa Rica & $<0.1$ & Cotton, soybeans \\
\hline 25 & Indonesia & $<0.1$ & Sugarcane \\
\hline \multirow[t]{2}{*}{26} & eSwatini & $<0.1$ & Cotton \\
\hline & Total & 191.7 & \\
\hline
\end{tabular}

*18 biotech mega-countries growing 50,000 hectares, or more, of biotech crops. Source: ISAAA, 2018.

\section{Nature of damage of EFSB}

Soft stems, flowers or fruits are injected by EFSB within one hour after larval hatching. Immediately boring into twigs or fruits, larva plug the entrance hole with excreta. Generally, caterpillars bore inside petioles and midribs of leaves followed by the affected leaves drop off [10]. Larval infested shoots also resulted with wilt. The presence of wilted shoots in an eggplant field is the confirmatory symbol of damage by EFSB. Larval infestation inside the fruit results in the damage of fruit. This makes even slightly to whole fruit damage resulting unfit for marketing [6].

2. Economic losses due to EFSB

As a part of prevention against ESFB, farmers have to use large number of chemical insecticides to get god quality fruit.

To prevent insect infestation, attempts with use of biological control have not been successful till now. During the cultivation of eggplant farmers face the EFSB larvae damage the eggplant shoots and fruit causing unmarketable of fruits. So, eggplant crops have to sprayed with insecticides indiscriminately over 80 times in a season of 6-7 months growing season in Bangladesh [37]. Farmers suffer from devastating health problems resulting from these insecticides due to repeated use of pesticides during the season, while also destroy beneficial pollinators, predatory insects and parasitoids that help in controlling the EFSB pest. Furthermore, EFSB has, in recent years, developed resistance to many of these pesticides thus rendering the sprays only partially effective.

\section{Bt Eggplant - an Effective and an Eco-friendly Strategy for Control of EFSB}

Introduction of the Bt gene into eggplant varieties using genetic engineering techniques conferred resistance to EFSB. The Bt gene has a specific mode of action restricted to lepidopteran insect pests. As an alternate strategy to control EFSB, BARI has developed nine varieties of $\mathrm{Bt}$ eggplant based on the regional consumption preference with the cry1Ac gene from Bacillus thuringiensis subsp. kurstaki (B.t. k.) tolerant to the EFSB. The Cry1Ac protein has a very specific mode of action. It is reported that the Cry proteins diffuse the midgut membrane of lepidopteran insects and bind with specific receptors on the midgut epithelium surface [20], [55].

The Cry $1 \mathrm{Ac}$ has a very specific mode of action. It has been well established that when Cry1 Ac is ingested by susceptible insects it is cleaved by gut enzymes that result in an active toxin. This active toxin binds to specific mid-gut receptors which result in the formation of pores. The pores lead to osmotic lysis resulting in gut paralysis and starvation [12], while provide the target specificity of each protein [20], [32], [55]. Organisms that do not have the necessary gut enzymes or receptors, as in the case of mammals, birds and fish are free from the toxic effects of Cry1Ac proteins.

\section{Characteristics of the Inserted crylAc Gene}

The introduced genetic material has been genetically optimized for its increased expression in plants. Both the regions of the cry $1 \mathrm{Ac}$ gene were genetically modified for increased plant expression that described by [43]. The DNA of Bacillus thuringiensis subsp kurstaki coding sequence was subjected to specific alterations which increased the level of Cry1Ac protein. Since the Cry1Ac protein produced in Bt eggplant an insecticidally active trypsin resistant core product of approximately 600 amino acids in size, the amino acid at position 766 will be lost in the insecticidal inactive fragment upon exposure to trypsin (or the proteases within the insect gut), this will not affect the host range or the active $\mathrm{N}$-terminal portion of the protein [7].

\section{Level and site of expression of the protein}

The levels of expression of Cry1Ac protein in Bt eggplant derived from eggplant event EE-1 was found to vary between 5 to $47 \mathrm{ppm}$ (an average obtained across all field trials $>55$ 
conducted by Mahyco in India). 30-day old nursery seedlings were transplanted into the main field; tissue sampling started from 30 days post-transplantation, and various plant parts were sampled at the appropriate time. Root expression was assayed at the end of the trial. The Cry1Ac protein was detected in fruits, shoots, leaves, stem and roots of eggplant plants.

2. Toxicity or allergenicity of any expressed substance $(s)$

Extensive biosafety evaluations were carried out on Event EE-1 (Data and study results are available in public domain) [24]. The collective evidence indicates that the Cry1Ac protein expressed in Bt eggplant is not toxic to mammals as these species lack receptors for the proteins on the surface of their gut cells [18]. Since Cry1Ac is a protein, its allergenic potential has been considered. As no one study can determine the allergenic potential of a protein, a weight of evidence approach has been considered, as recommended by CODEX [16]. The donor organism for cry1Ac gene is Bacillus thuringiensis, which is not known to be allergenic or a source of allergens. Information previously available for Cry1Ac has shown that Cry1Ac does not show homology to known allergens [8]. The protein is also rapidly inactivated by heat treatment, and there rapidly degraded in simulated gastric fluid. It can be concluded that Cry1Ac is unlikely to be toxic or allergenic to humans.

3. CrylAc protein to known protein toxins and allergens

The Cry1Ac protein was compared to known protein toxins in the PIR, EMBL, SwissProt and GenBank protein databases [29]. Results from this search established that, there are no changes of biologically significant homologies between the protein sequence of known toxins and the Cry1Ac protein sequence. Searches of protein sequence allergen databases also did not show any significant matches of the Cry1Ac protein to known allergens [38].

\section{Toxicity of purified CrylAc protein}

The cry1Ac gene in the plasmid pMON 10518 that was used in the transformation of Bt eggplant is the same as that of the plasmid pMON 531 which was used in the transformation of $\mathrm{Bt}$ cotton. This cry1Ac gene encodes for Cry1Ac (Bacillus thuringiensis var kurstaki (B.t.k.)) HD-73 protein. The acute oral toxicity studies of Bacillus thuringiensis Var. Kurstaki [Cry1A(c)] HD-73 protein conducted by Monsanto in Albino mice in the study with reference number ML-92-493 indicates that there was no adverse effect in the mice groups administered B.t.k. HD-73 protein by oral gavage at dosages up to $4200 \mathrm{mg} / \mathrm{kg}$.

\section{Allergenicity of CrylAc protein}

The donor organism for Cry1Ac is Bacillus thuringiensis, which is not known to be allergenic or a source of allergens. Information previously available for Cry1 Ac has shown that Cry1Ac does not show homology to known mammalian allergens. The protein is also rapidly inactivated by heat treatment and shows rapid degradation in simulated gastric fluid. The Cry1Ac does not show glycosylation a food allergen proteins and degradation by high temperature, acid and proteases of the digestive system [5].

\section{Digestive fate of CrylAc}

The Cry1Ac protein was examined in gastric (pepsin, $\mathrm{pH}$ 1.2) and intestinal (pancreatin, $\mathrm{pH}$ 7.5) fluid for rate of degradation [48]. No Cry1Ac protein was detected by western blot analysis after incubation in gastric fluid for 30 seconds.

7. Gross composition of the plant in comparison to the untransformed plant

A comparative study of the nutritional composition was conducted comparing different lines of Bt eggplant with four non-Bt eggplant controls. The data obtained from the study indicated that there were no appreciable differences between Bt eggplant and non-Bt eggplant groups in the chemical constituents of water, protein, fat, carbohydrates, total dietary fibre and ash content by proximate analysis, metal (Ca, Mg, Fe, Zn, Cu, Mn, K, P, Na) content by AAS analysis and vitamin A, B1, B2, C content by HPLC method and vitamin B6 by microbial assay (Analytical Report, 2013). These results suggest that the genetic modification introduced in $\mathrm{Bt}$ eggplant has resulted in biologically relevant in composition compared to conventional eggplant.

\section{E. Environmental Safety Assessment}

The purpose of environmental risk assessment for transgenic crops is to evaluate the risks associated with the cultivation of GM eggplants vs. conventional eggplant, which typically has a history of safe use. Since the regulatory perspective, BARI has examined studies to assess the impact of the $\mathrm{Bt}$ protein $\mathrm{Cry} 1 \mathrm{Ac}$ on non-target organisms, soil microflora of soil and variations in pests and disease susceptibility.

\section{Impact on non-target organisms}

Since Cry1Ac has insecticidal properties against certain Lepidoptera species the potential harm for non-target arthropods has been assessed. Tests on a range of non-target arthropods with purified Cry1Ac protein have been conducted to support the environmental risk assessment of different crops expressing Cry1Ac (CERA, 2010). None of the organisms tested showed any significant response to Cry1Ac at high test concentrations. These results show that the cultivation of Bt eggplant is unlikely to result in adverse effects on non-target organisms. To confirm, BARI conducted several multilocation field trials during 20102013. The field trials confirm that there is no evidence that Cry1Ac as expressed in Bt eggplant will have an adverse effect on non-target organisms viz., aphids, jassids, whitefly, epilachna beetle and lady bird beetle [45].

\section{Effect on Soil microflora}

Bt eggplant cultivated soil was examined by BARI to analyze the effect of Cry1Ac protein on soil microflora. The studies were conducted on multiple locations using $9 \mathrm{Bt}$ eggplant varieties and their non-Bt counterparts during 201013. Soil samples were taken to study the effect of Cry1Ac on commonly found soil microorganisms such as Azotobacter, Rhizobium and populations of phosphate solubilising bacteria in the soil and analyzed in the Soil Microbiology Laboratory at BARI and its stations using standard microbiological procedures. The results show that the soil microflora is not dependent on the Bt trait gene present in eggplant and confirmed that the Cry1Ac protein has no toxic effect on soil microflora was found.

\section{Crossability}

The genus Solanum is a very large genus to which eggplant belongs and have a wide diversity and have the classification of cultivar into several phenotypic groups [36]. Wild species 
such as S. indicum, S. sisymbriifolium, S. nigrum and $S$. torvum were not cross compatible with the cultivated $S$. melongena. A few seeds were produced while crosses were done among the of the cultivated $S$. melongena with wild $S$. torvum, but those seeds failed to germinate [47]. The same type of results was conducted by [17], [26], [31], [34], [44]. It was also found that $S$. melongena was crossable with $S$. incanum. However, even though they are crossable, $S$. melongena and $S$. incanum co-exist in nature since long time with their diversity in nature and there is no chance to decreased.

\section{Outcrossing of eggplant}

Eggplant is a highly self-pollinated crop, while a certain percentage of outcrossing can occur. When the stigma is parallel to anthers generally occurs self-pollination; there is a great chance for cross-pollination, while the stigma develops beyond the anthers. Generally, the natural cross pollination mainly depends on variety, season, location, environmental condition, and pollinator activity. The findings of out-crossing have been reported in China (3 to $7 \%$ ) and at AVRDC (0 to 8.2\%) [13]; while some Indian findings have reported 0 to $48 \%$ out-crossing in India [1], [14], [15], [49]. The outcrossing studies conducted by Mahyco for Event EE-1 derived hybrids reported $0.07 \%$ to $2.7 \%$.

\section{Pollen flow}

Studies were conducted in India by Mahyco to confirm the extent of outcrossing in $S$. melongena with sexually compatible wild species including relatives with genetic compatibility. As per the study carried out by Mahyco on the Bt eggplant lines developed at Mahyco, the maximum distance 15-20 meters traveled by the pollen and the outcrossing was 1.46-2.7\%. It also studied that Bt eggplant did not show any weediness and behaved similarly as non-Bt isolines [35]. The results showed that genetic modification has not affected the outcrossing potential of S. melongena. It is to be noted that, since pollen of eggplant can travel relatively short distance, unwanted outcrossing of $\mathrm{Bt}$ eggplant to the non-Bt eggplant varieties can be easily prevented.

\section{Gene transfer from eggplant to other organisms}

Horizontal gene transfer from plants to microorganisms or animals, humans is totally unlikely. No evidence has been identified for any mechanism by which plant genes could be transferred to any animals or humans, nor any evidence that such gene transfer has occurred for any plant species during evolutionary history, since animals and humans are eating a large quantities of plant DNA for a long time. So, there is no chance of eggplant genes transferring to humans and other animals. Likewise, gene transfer from any other plant or eggplant to microorganisms is totally ridiculous. Under the natural condition, horizontal gene transfer from plants to bacteria has not been experimentally demonstrated [42] and deliberate attempts have so far failed to induce such transfers [30].

\section{Germination, Aggressiveness and Weediness}

To assess the germination rate of Bt eggplant, a study was conducted by BARI where Bt eggplant lines were compared in soil to their non Bt counterparts. The results revealed that there were no significant differences in germination rate or vigour between $\mathrm{Bt}$ and non-Bt eggplant. Phenotypic characteristics indicative of weediness potential was also compared between Bt eggplant and a non Bt counterpart. The results showed that there were no differences in weediness or aggressiveness potential between $\mathrm{Bt}$ eggplant and the non $\mathrm{Bt}$ counterparts. These sequences were examined by Mahyco to monitor the aggressiveness of Bt eggplant as compared to its isogenic counterparts. In general eggplant does not bear any characters like weediness, seed dormancy, soil persistence, rapid vegetative growth, a short life cycle, high seed output and dispersal [23].

\section{Socio-economic assessment}

The socio-economic assessment indicates that the adoption of Bt eggplant varieties will result in $70-90 \%$ decrease in pesticide usage in eggplant crop cultivation and an unprecedented yield percentage increase of $113 \%$. Considering the farmer cost price as Bangladesh Taka (BDT) 10 per kilogram of eggplant, the mean value realized indicates a net economic gain of Taka (BDT) 68,438 per hectare with the cultivation of Bt eggplant varieties over the non-Bt eggplant. This reflects an overall mean increase of $118 \%$.

\section{F. Regulatory Process for GMO in Bangladesh}

\section{National Biosafety Framework (2006)}

In Bangladesh, the National Biosafety Framework (NBF) provides the basis for future regulation for the management of any kind of biotechnology GMO products. The NBF consists of the following elements:

1) National policy and guidelines biosafety,

2) Legal regime,

3) Administrative system,

4) Monitoring and enforcement systems

5) Public participation, education and awareness procedures.

\section{Biosafety Rules of Bangladesh}

The Biosafety Rules, the key legal document that regulates the development, import, export, use, and movement of all GMO products. The law provides for disciplinary measures against the misuse of GMO products. The Biosafety Guidelines of Bangladesh are legally attached under the Biosafety Rules. The Ministry of Environment, Forests and Climate Change (MoEF) is the national authority to impose the Biosafety Rules. These rules apply to the GMOs, microorganisms and cells and correspondingly to any substances and products and food stuffs, etc. of which such cells, organisms or tissues thereof form part. These rules shall also be applicable in the following specific cases; of sale, export, production and all work involved in the field trial of GM plants, animals (including fisheries, poultry, animal and marine life), micro-organisms and cells [19].

\section{Biosafety Guidelines in Bangladesh}

To ensure the environmentally safe application of modern biotechnology, biosafety is used. It will ensure the application of modern biotechnology in medicine, agriculture, fisheries and livestock, and in environmental issues, without threatening to public and animal health or environmental concern. It is notable to mention that when Cartagena Protocol on Biosafety to the Convention on Biological Diversity (CBD) was not in place Biosafety Guidelines in Bangladesh was first formulated by the Ministry of Science and Technology in 1999. Bangladesh 
approved the Protocol in 2004. Considering the obligation of the Protocol, the guidelines have been updated by the [41], in accordance with the latest information. So, the Biosafety guidelines are must applicable to all modern biotechnology research activities of the government research institutes, state enterprises, universities, international organizations, private companies or non-governmental organizations located in Bangladesh. The objective of these guidelines is to safeguard an adequate level of protection in the laboratory, field trial, safe transfer, handling, use and transboundary movement of GMOs as part of modern biotechnology that may have adverse effects on the conservation and sustainable use of biological diversity, taking also into account risks to human and animal health. Based on the precautionary principle, the guidelines provide a framework for the following aspects:

a. Develop acts, rules, standards and scientific database, codes of practice and monitoring capabilities and enforcement manuals for assessing risk in the research and release of GMOs into the environment.

b. Provide the basis to ensure safety of the developers and end-users of modern biotechnological products.

c. Foster the development and enforcement of regulations.

d. Promote a favorable climate for developing and accelerating innovation and for adopting sustainable biotechnology products and processes.

The Biosafety Guidelines of Bangladesh covers aspects of risk assessment and safety requirements needed for the undertaking- Laboratory work, field trial and commercial use, involving (i) Microorganisms (ii) plants, (iii) animals.

\section{Biosafety Committees}

The MoEF is the national authority and concern national focal point to implement Cartagena Protocol on Biosafety to the CBD, established a National Committee on Biosafety (NCB) which will ensure safety modern biotechnological activities including research and development, introduction, use and transboundary movement of GMOs/LMOs. To assist and accelerate the activities of NCB, a Biosafety Core Committee (BCC) is formed. In the laboratories and field activities there are several committees under NCB to ensure safe management of biosafety activities, such as the Institutional Biosafety Committee (IBC), Field Level Biosafety Committee (FBC) and also there are designated Biological Safety Officers (BSO) in each research establishment of the country. Each Committee has separate specific functions and responsibilities

5. Regulatory process for GMO research in Bangladesh

The administrative approval process for research on GMOs as per the Biosafety guidelines may vary from field to field depending on the level and type of Biosafety. In general, the approvals for research work on GMOs in Bangladesh are as follows.

- Laboratories wishing to research on GMOs must be get permission from the MoEF, Bangladesh. Such permission will be based on the level of vitality of the organism that seeks to conduct research. Once approved, the laboratory will be registered by the Member Secretary of the National Committee on Biosafety (NCB).

- Except for Biosafety Level-1 for GMO research will require NCB approval for each import of other levels (Biosafety Level-2, 3, 4). The NCB may, if necessary, inform the Customs Department of Port of entry about the import permit.

- A detailed list is mentioned in Sections 3.1.6 and 3.1.9 of the Bangladesh Biosafety Guidelines, while application submission for seeking permission for research.

- Licensed laboratories for research on GMOs should follow the 'Good Laboratory Practice' in accordance with the Bangladesh Biosafety Guidelines Annex-2.

- All laboratories have to follow any rules and regulations of the Ministry of Commerce while importing biotechnology related products.

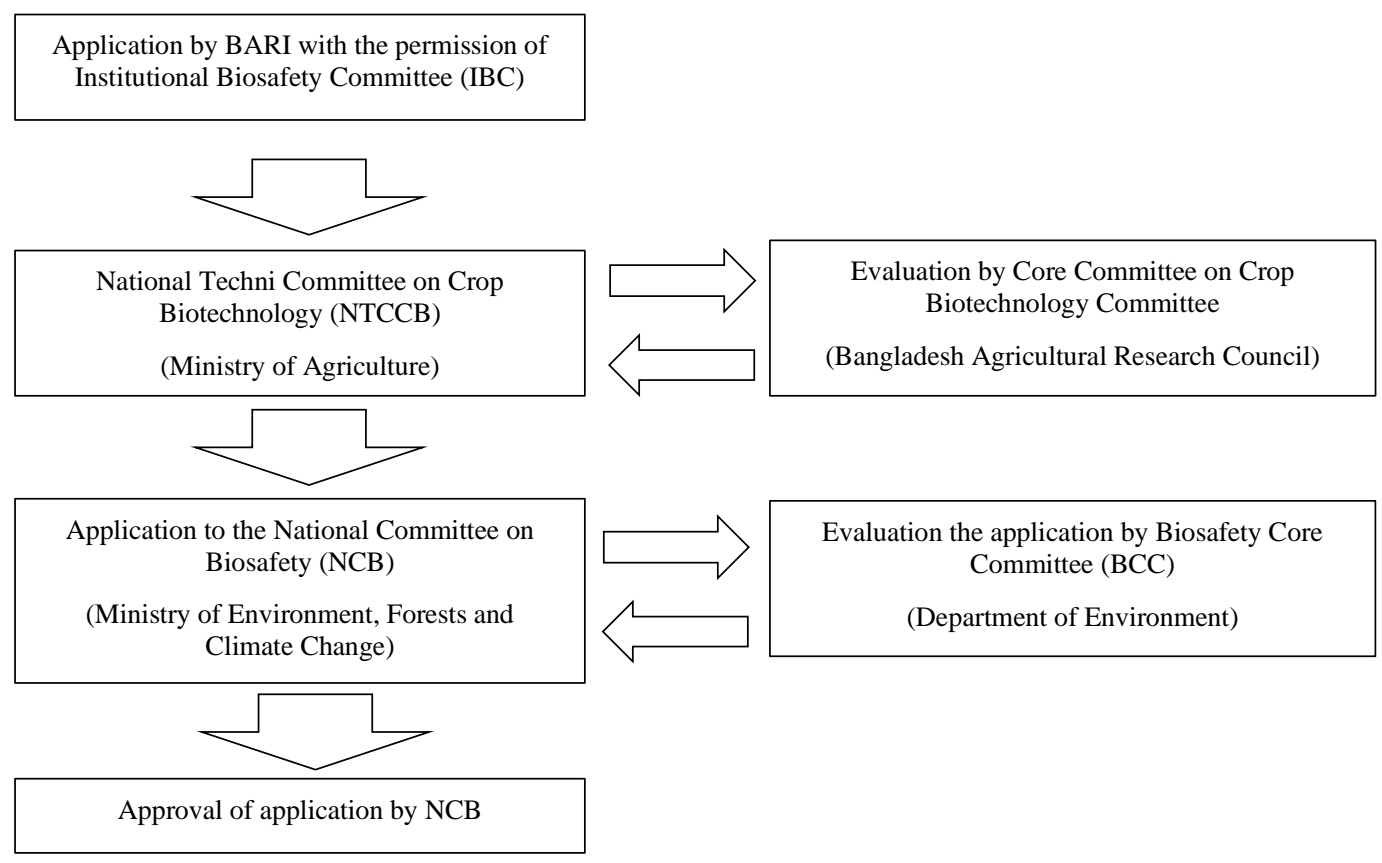

Fig. 2. GM crops approval system in Bangladesh. 


\section{G. Inception and Generation Advancement of Bt Eggplant at BARI}

Mahyco has developed Bt eggplant event EE-1 using Cry1Ac gene with the technical cooperation of Cornell university and Monsanto seed company, USA. Various animals including fish, birds, chicken, goat, cattle, rabbit were tested against $\mathrm{Bt}$ gene in more than 10 world renowned accredited laboratories in different developed countries of the world, and no toxic effect of Bt eggplant was noticed on them. Allerginess, environmental and other animal safety tests found no negative results of Bt gene. To provide biotech information to scientists, extension workers, farmers and public in developing countries and to assist in the safe application and commercialization of genetic engineering as a complement to conventional agricultural activities, ABSP2 (Agricultural Biotechnology Support Project II) project funded by USAID and supervised by Cornell University was launched in Bangladesh in 2002.

A Memorandum of Understanding (MoU) was signed between Bangladesh Agricultural Research Council (BARC) and the Cornell University of USA on June 27, 2004. Under the public-private partnership, ABSP-2 project, BARI, Mahyco, Sathguru management consultants of India, and Cornell University started the work of Bt eggplant research in Bangladesh. Although the ABSP-2 project was completed in 2014, USAID has been providing financial support for the development and expansion of Bt eggplant through the South Asia Eggplant Improvement Partnership (SAEIP) project since 2015. BARI and Mahyco signed a sublicense agreement on March 14, 2005, regarding the utilization of Bt genes and the development of $\mathrm{Bt}$ eggplant. The contract was later renewed on July 5, 2019.

According to the agreement, Bt gene is owned by Mahyco, however, the 9 varieties of eggplant used in Bangladesh will be owned by BARI. Under the ABSP-2 project, two BARI scientists went to Mahyco for training. During the training, the Cry1Ac gene, which is resistant to eggplant fruit and shoot borer insect, was transferred through the hybridization of EE-1 eggplant of Mahyco with 9 varieties of Bangladesh such as BARI Brinjal-1, BARI Brinjal-4, BARI Brinjal-5, BARI Brinjal-6, Singhnath, Khatkhatia, Islampuri, Dohazari and Chega. With the approval of the Government of Bangladesh, the transgenic seed of Backcross-1 was handed over to BARI and later confined greenhouse and contained multilocation field trial was conducted. BARI started research on $\mathrm{Bt}$ eggplant in 2005 by forming a multidisciplinary team of biotechnologists, horticulturists, plant pathologists, entomologists, soil scientists and economists for the project. Confined greenhouse research on transgenic varieties was carried out by collecting eggplant fruit and shoot from four important regions of the country.

\section{H. Timeline of BARI initiated research activities [4]}

2005 : Hybridization of nine Bangladeshi eggplant cultivars with Bt eggplant variety (EE1) at Mahyco and F1 seeds were collected, and backcrossing programme initiated (BC1) at Mahyco, India.

2006 : BC2 done at BARI, Bangladesh

2007 : BC3 done at BARI, Bangladesh

2008 : BC3(F2) done at BARI, Bangladesh

2009 : BC3(F3), BC4 done at BARI, Bangladesh
2010 : BC3(F4), BC5 done at BARI, Bangladesh

Multi-Location trials (MLTs) were conducted at 7 locations

2011 : BC3(F5) done at BARI, Bangladesh

MLTs were conducted with 9 varieties at 7 locations

2012 : MLTs were repeated with 9 varieties at 7 locations

2013 : MLTs were repeated with 9 varieties at 7 locations

Proposed $4 \mathrm{Bt}$ version lines as new $\mathrm{Bt}$ brinjal variety.

2013 (30 October), Launched 4 new Bt brinjal variety viz., BARI Bt Brinjal-1, BARI Bt Brinjal-2, BARI Bt Brinjal3, BARI Bt Brinjal-4.

TABLE II: MAJOR CHARACTERS OF FOUR BT BRINJAL VARIETIES

\begin{tabular}{|c|c|c|c|c|}
\hline Characters & $\begin{array}{l}\text { BARI Bt } \\
\text { Brinjal-1 }\end{array}$ & $\begin{array}{l}\text { BARI Bt } \\
\text { Brinjal-2 }\end{array}$ & $\begin{array}{l}\text { BARI Bt } \\
\text { Brinjal-3 }\end{array}$ & $\begin{array}{l}\text { BARI Bt } \\
\text { Brinjal-4 }\end{array}$ \\
\hline $\begin{array}{c}\text { Growth } \\
\text { habit }\end{array}$ & Prostrate & Prostrate & Intermediate & Intermediate \\
\hline Stem color & $\begin{array}{l}\text { Purple } \\
\text { brown }\end{array}$ & $\begin{array}{l}\text { Purple } \\
\text { brown }\end{array}$ & Purple green & Light green \\
\hline $\begin{array}{c}\text { Bearing } \\
\text { habit }\end{array}$ & Cluster & Cluster & Solitary & Solitary \\
\hline Fruit shape & Elliptical & Cylindrical & Round & Oval \\
\hline $\begin{array}{l}\text { Fruit skin } \\
\text { color }\end{array}$ & Purple & $\begin{array}{c}\text { Purple } \\
\text { black }\end{array}$ & Purple black & Light green \\
\hline $\begin{array}{c}\text { Fruit } \\
\text { glossiness }\end{array}$ & Glossy & Glossy & Glossy & Glossy \\
\hline $\begin{array}{l}\text { Average } \\
\text { fruit } \\
\text { weight (g) }\end{array}$ & $80-90$ & $110-120$ & $150-160$ & $200-230$ \\
\hline $\begin{array}{c}\text { Number of } \\
\text { fruits/ } \\
\text { plants }\end{array}$ & $70-80$ & $30-35$ & $15-20$ & $15-17$ \\
\hline $\begin{array}{l}\text { Fruit yield } \\
\text { (t/ha) }\end{array}$ & $50-55$ & $45-50$ & $45-50$ & $40-45$ \\
\hline
\end{tabular}

\section{Seed Production Program of Bt eggplant Varieties at BARI}

The Biotechnology Division of BARI commenced multiplication of seeds since 2013. Afterword, a three-year seed production program was worked at BARI during 201417, financed by the Ministry of Agriculture, Bangladesh to produce enough seeds of the four released varieties of $\mathrm{Bt}$ eggplant. The program was implemented by Seed Technology Division of BARI in collaboration with Biotechnology Division and Horticulture Research Centre, BARI. Adequate seeds of four varieties were produced under this program (Table III). Bangladesh Agricultural Development Corporation (BADC), a government organization, is also producing Bt eggplant seeds. While private seed companies also applied to proper authority for seed production and marketing of Bt eggplant but the decision yet not finalizes.

TABLE III: SEED PRODUCTION By SEED TECHNOLOGY Division, BARI DURING 2014-17 (APAARI, 2018)

\begin{tabular}{|c|c|c|c|}
\hline Year & 2014-15 & $2015-16$ & 2016-17 \\
\hline BARI Bt Begun-1 & 0.8 & 153.5 & 234.0 \\
\hline BARI Bt Begun-2 & 28.5 & 184.0 & 337.0 \\
\hline BARI Bt Begun-3 & 4.5 & 84.0 & 202.0 \\
\hline BARI Bt Begun-4 & 4.5 & 239.0 & 245.0 \\
\hline Total & 38.3 & 660.5 & 1018.0 \\
\hline
\end{tabular}

\section{J. Study on Infestation of BFSB in Bt and non-Bt Brinjal Field}

According to different demonstration trials conducted by $\mathrm{BARI}$, the performance of $\mathrm{Bt}$ eggplant was far superior to 
non-Bt eggplant, while the fruit infestations in Bt eggplant was very insignificant ranging from $0.04-0.88 \%$ compared to $48-57 \%$ in the non-Bt eggplant [40]. A study was conducted by [45] to study the effect of spray and no-spray in Bt and non-Bt isolines of brinjal varieties in 2017. Significant differences were observed among the varieties for BFSB infestation (Table IV). There was no shoot and fruit infestation by EFSB in any of the four Bt brinjal varieties in both spray and no-spray treatment. But lower infestation was observed in shoot of non-Bt isolines varieties compared to fruit in both sprays (0.61-2.24\%) and no-spray (0.92-1.75\%) treatment. The infested fruit in both spray and no-spray was higher in non-Bt isoline brinjal varieties. The range of infestation was $32.38-44.30 \%$ in spray and $10.93-35.21 \%$ in no-spray treatment. In both the spray and no-spray conditions, the Non-Bt isoline-1 produced the maximum number of infested fruits (44.30 and $35.21 \%)$. Fruit infestation was calculated by percent fruit weight, which was more reflective of income because brinjal is sold by weight and infested fruit brings a lower value [45].

\section{K. Yields and Gross Margins of Bt Brinjal}

Due to EFSB infestation and spraying costs in eggplant cultivation, significant differences were shown in economic returns (Table V). Bt eggplant has higher gross return and gross margins than their counterpart Non-Bt isolines, whether they were sprayed by insecticide or not. In both the spray and no-spray treatment, BARI Bt Begun-1 gained higher gross margin $(3,654.59 \$ /$ ha and $1,289.78 \$ /$ ha $)$ compare to Non-Bt isoline (541.64\$/ha and -294.59 \$/ha) [45].

TABLE IV: MEAN INFESTATION IN BRINJAL By EGGPLANT FRUIT AND SHOOT BORER (BFSB) RELATIVE TO INSECTICIDES REGIMES AND VARIETY, OFRD,

\begin{tabular}{|c|c|c|c|}
\hline Spray schedule & Variety & Infested shoot (\%) & Infested fruit (by wt) (\%) \\
\hline \multirow[t]{8}{*}{ Spray } & BARI Bt begun-1 & $0.00(0.00) \mathrm{c}$ & $0.00(0.00) \mathrm{d}$ \\
\hline & BARI Bt begun-2 & $0.00(0.00) \mathrm{c}$ & $0.00(0.00) \mathrm{d}$ \\
\hline & BARI Bt begun-3 & $0.00(0.00) \mathrm{c}$ & $0.00(0.00) \mathrm{d}$ \\
\hline & BARI Bt begun- 4 & $0.00(0.00) \mathrm{c}$ & $0.00(0.00) \mathrm{d}$ \\
\hline & Non-Bt isoline-1 & $1.14(0.32) \mathrm{b}$ & $44.30(0.02) \mathrm{a}$ \\
\hline & Non-Bt isoline-2 & $0.61(0.06) b$ & $36.88(0.08) \mathrm{ab}$ \\
\hline & Non-Bt isoline- 3 & $2.24(0.09) \mathrm{a}$ & $40.14(0.21) \mathrm{a}$ \\
\hline & Non-Bt isoline-4 & $1.60(0.12) \mathrm{ab}$ & $32.38(0.45) \mathrm{ab}$ \\
\hline \multirow[t]{8}{*}{ No- Spray } & BARI Bt begun-1 & $0.00(0.00) \mathrm{c}$ & $0.00(0.00) \mathrm{d}$ \\
\hline & BARI Bt begun-2 & $0.00(0.00) \mathrm{c}$ & $0.00(0.00) \mathrm{d}$ \\
\hline & BARI Bt begun-3 & $0.00(0.00) \mathrm{c}$ & $0.00(0.00) \mathrm{d}$ \\
\hline & BARI Bt begun-4 & $0.00(0.00) \mathrm{c}$ & $0.00(0.00) \mathrm{d}$ \\
\hline & Non-Bt isoline- 1 & $1.43(0.14) \mathrm{ab}$ & $35.21(0.41) \mathrm{ab}$ \\
\hline & Non-Bt isoline- 2 & $0.92(0.13) \mathrm{ab}$ & $18.31(0.38) b c$ \\
\hline & Non-Bt isoline-3 & $1.75(0.16) \mathrm{ab}$ & $10.93(0.37) \mathrm{c}$ \\
\hline & Non-Bt isoline- 4 & $1.39(0.10) \mathrm{ab}$ & $10.99(0.23) \mathrm{c}$ \\
\hline
\end{tabular}

Figures in parenthesis are SE values; means followed by the same letter in a column do not significantly differ from each other at $5 \%$ level by HSD.

TABLEV: MEAN YIELDS AND ECONOMIC RETURNS1 IN BRINJAL BY EGGPLANT FRUIT AND SHOOT BORER (EFSB) RELATIVE TO INSECTICIDES AND VARIETIES, OFRD, BARI, BOGRA, BANGLADESH [45]

\begin{tabular}{|c|c|c|c|c|c|c|}
\hline \multirow{2}{*}{ Year } & \multirow{2}{*}{$\begin{array}{c}\text { Spray } \\
\text { schedule }\end{array}$} & \multirow{2}{*}{ Variety } & \multicolumn{2}{|c|}{$\begin{array}{l}\text { Fruit yield (t/ha) } \\
\end{array}$} & \multirow{2}{*}{ Gross return $(\$) / \mathrm{ha}^{2}$} & \multirow{2}{*}{ Gross margin (\$)/ha } \\
\hline & & & Non-infested fruit & Infested fruit & & \\
\hline \multirow[t]{3}{*}{2017} & Spray & BARI Bt Begun-1 & $19.88(1.25) \mathrm{a}$ & $0.00(0.00) \mathrm{c}$ & $5,912.77(371.76) \mathrm{a}$ & $3,654.59(371.76) \mathrm{a}$ \\
\hline & & Non-Bt isoline & $8.73(0.80) b$ & $8.48(0.71) \mathrm{a}$ & $2,799.82(252.03) \mathrm{b}$ & $541.64(252.03) b c$ \\
\hline & & Non-Bt isoline & $2.63(0.32) \mathrm{c}$ & $2.55(0.16) b$ & $844.61(99.34) \mathrm{c}$ & $-294.59(99.34) \mathrm{c}$ \\
\hline
\end{tabular}

${ }^{1}$ Figures in parenthesis are SE values; means followed by the same letter in a column do not significantly differ from each other at $5 \%$ level by HSD; 1 US dollar = 84.05 Bangladeshi Taka (29 March 2018).

\section{Adoption of Bt Eggplant in Bangladesh}

For the first time, Bt eggplant seedlings were distributed among 20 farmers in four districts of Bangladesh on 22 January 2014. In the second year of Bt eggplant production, BARI provided seedlings to 108 farmers of On-farm Research Division (OFRD) to conduct field demonstration trials in 19 districts. The number of demonstration trials was increased in next year likewise, 250 farmers in 25 districts in 2015-16 and 512 farmers in 36 districts 2016-17. In 2017-18, BARI distributed seeds to 569 farmers in 40 districts. Department of Agricultural Extension (DAE) also distributed seeds to 6,000 and 7,001 farmers in 2016-17 and 2017-18, respectively, while BADC has sold seed to an additional 17,950 farmers in 2018 [51].

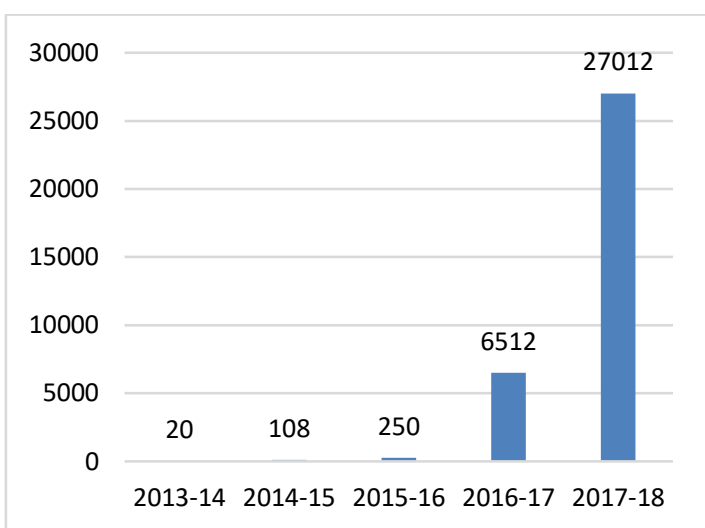

Fig. 3. Bt eggplant cultivated farmers in Bangladesh during 2013-18.

\section{Stewardship of Bt Eggplant in Bangladesh}

Bangladesh became the 23rd country in the world to allow commercial cultivation of genetically modified crops (Bt eggplant) in 2013 [25], while seedlings of four eggplant 
varieties were distributed to 20 farmers in 2014. In subsequent years the adoption has increased rapidly resulting 27,012 farmers cultivated the Bt eggplant in 2018 and gained profit using the first GM crop. The expansion of cultivation of Bt eggplant among the farmers was supported by USAID project, while whole activities is leaded by Bangladesh Agricultural Research Institute (BARI). As a part of stewardship, BARI has trained the concern farmers, extension workers and prepared production technology manual, creating awareness among the stakeholders, on-farm trial, baseline susceptibility, refuge management, capacity building for researchers and extension workers, field monitoring, good quality seed production, packaging, distribution and tracing of seed, expression of $\mathrm{Bt}$ gene in the product, agronomic and economic performance of cultivation, consistent communication with stakeholders etc.

Due to the performance of Bt eggplant is quite satisfactory so far, a lot of awareness and interest has been grown among the farmers. The expansion of Bt eggplant in Bangladesh, may be a milestone for futures other GM crops development. The new workable areas may be on wilt resistant, hybrid development, refuge mixing, incorporation of multiple genes etc. and requires also good stewardship in future.

By this time, good stewardship practices for Bt eggplant have been developed being practices in Bangladesh. As with any insect control crop, it is tried for Bt eggplant must be incorporated within an Integrated Pest Management (IPM) program. The Cry1Ac protein controls the main pest (EFSB) but does not any affect on other eggplant non-target pests viz., leafhoppers, whiteflies, aphids and thrips, all of which may causes yield loses of eggplant. Several studies have been conducted to develop thresholds for these non-target pests. As part of an Insect Resistance Management (IRM) program, baseline susceptibility of EFSB for CrylAc is being determined to ensure the long-term benefit of this technology. As an important component of IRM, farmer plots are incorporated with refuge management. From the very beginning of this technology, farmer-training programs are being conducted, since farmers are ultimately the ones who will need to protect this valuable technology. The field demonstrations conducted during 2014 to 2019 clearly showed the benefit of Bt eggplant for control of EFSB, and growers were highly satisfied with their experiences. Interviews with growers are available in website [21], and readers are urged to view the 22 June 2017 video [9].

\section{N. The Regulatory System in Bangladesh}

Most of the countries are based on an event-based approval process. But in Bangladesh registration system for GMO crop is variety-based registration system. The efficiency and cost of event-based registration helps move a product to market more rapidly. So, it is better to introduce event-based system rather than variety-based system. Numerous studies have shown in Bt eggplant release process does not compromise efficacy or safety. Discussions are underway in Bangladesh that may help them adopt an event-based system to allow more rapid development of $\mathrm{Bt}$ varieties by BARI and the private sector. It is also needed to assess compliance of regulations affecting $\mathrm{Bt}$ eggplant at all levels from the laboratory to the field, and this could be a function of Excellence Through Stewardship (ETS). Likewise, efforts should also explore the potential use of "refuge in the bag" (Separate Bt and non-Bt seed in the same packet) technology to ensure farmer refuge compliance [51].

Based on the above information and data, deregulation and commercialization of $\mathrm{Bt}$ eggplant in Bangladesh have alleviated poverty, improved socio-economic conditions and reduced the health hazards for farmers due to uncontrolled pesticide use.

\section{CONCLUSION AND RECOMMENDATION}

Eggplant is one of the most common, popular and major vegetable crops grown throughout the year in all geographical parts of Bangladesh. As EFSB is the devastating pest of eggplant and for controlling this pest farmers frequently apply large quantities of chemical insecticides singly or in combination indiscriminately to get blemish-free fruits, which fetch premium prices in the market, but the success is very poor. To reduce pest-linked damage in eggplant crop, increase marketable yields, protect the environment and also ensure the health of the farmers by protecting them from the adverse effects of pesticides, the development of the EFSB resistant eggplant has been undertaken. Introduction of the $\mathrm{Bt}$ gene into nine Bangladeshi popular eggplant varieties using genetic engineering techniques conferred resistance to EFSB. The $\mathrm{Bt}$ gene has a specific mode of action restricted to lepidopteran insect pests. The Cry1Ac protein expressed by the cry1Ac gene has a very specific mode of action. Bangladesh started research work on development of $\mathrm{Bt}$ eggplant in 2005 in collaboration with the Cornell University, USA, and Mahyco, India under Agricultural Biotechnology Support Project II (ABSP II) with the financial support of United State Agency for International Development. Following the different breeding procedures and biosafety rules, BARI has developed four varieties of Bt eggplant viz., BARI Bt Begun-1, BARI Bt Begun-2, BARI Bt Begun-3, BARI Bt Begun-4 and got the permission for cultivation on 30 October 2013. Numerous studies have been conducted during the Bt brinjal release process does not compromise efficacy or safety. Substantial equivalence was demonstrated to ensure that Bt brinjal meets food and feed safety standards. $\mathrm{Bt}$ brinjal was found to be nutritionally and compositionally equivalent to non-transgenic eggplant. After a rigorous regulatory process, laboratory and field trials, Bt eggplant varieties were made possible to the farmers for cultivation. Cultivation of Bt eggplant varieties was considered the best option by the farmers and the adoption of Bt eggplant varieties increased rapidly by about 27012 Bangladeshi farmers in 40 districts by 2017-18 with favorable socioeconomic benefits. The advancement and development of Bt eggplant in Bangladesh were made possible because the government and people of Bangladesh have embraced science-based technologies to improve the livelihoods of smallholder farmers.

\section{ACKNOWLEDGEMENT}

The author gratefully acknowledges the support of Anthony M. Shelton, Professor, Entomology Cornell AgriTech, Cornell University, USA; M.Z.H. Prodhan, Tuber 
Crops Research Centre, BARI, Bogura, Bangladesh; Md. Kamrul Hasan, BARI, Gazipur, Bangladesh; Md. Jahangir Hossain, Country Coordinator, FtF Biotech Eggplant, Bangladesh; Vijay Dattatraya Paranjape, Sathguru Management Consultants, Hyderabad, India and also grateful for the help provided by the Bangladesh Agricultural Research Institute.

\section{REFERENCES}

[1] Agrawal, R.L. 1980. Seed Technology, Oxford and IBH Publishing Co., New Delhi, pp. 198-201.

[2] Analytical Report on Nutritional Value of Supplied Egg Plants. 2013. Institute of Nutrition and Food Science, University of Dhaka.

[3] Anonymous. 2020. Year Book of Agricultural Statistics of Bangladesh 2018. Bangladesh Bureau of Statistics, Ministry of Planning, Government of Peoples Republic of Bangladesh, Dhaka, Bangladesh. pp 249-290.

[4] APAARI. 2018. Success Story on Bt Brinjal in Bangladesh. AsiaPacific Association of Agricultural Research Institutions, Bangkok, Thailand. xviii $+39 \mathrm{p}$.

[5] Astwood, J.D., Leach, J.N. and Fuchs, R.L. 1996. Stability of food allergens to digestion invitro. Nature Biotechnology. 14:1269-1273.

[6] Atwal, A.S. 1976. Agricultural pests of Indian and Southeast Asia. New Delhi: Kalyani Publishers. 529 pp.

[7] Bietlot, H., Carey, P.R., Kaplan, H., Lessard, T., and Pozsgay, Z. 1989. Facile preparation and characterization of the toxin from Bacillus thuringiensis var. kurstaki Biochem. 260: 87-91

[8] Biopesticide, 2010. Biopesticide Registration Action Document. Bacillus thuringiensis Cry1 Ac Protein and the Genetic Material (Vector PV-GMIR9) Necessary for Its Production in MON 87701 (OECD Unique Identifier: MON 877Ø1-2) Soybean [PC Code 006532].

[9] Bt brinjal in Bangladesh: Voices from the Field.

[10] Butani, D K and Jotwani,M G 1984 Insects inVegetables Periodical Expert Book Agency. D-42, Vivek Vihar, Delhi-110032, India, 356 p.

[11] Caguiat XGI, Hautea DM. 2014. Genetic diversity analysis of eggplant (Solanum melongena L.) and related wild species in the Philippines using morphological and SSR markers, Sabrao J Breed Genet. 46(2): 183-201.

[12] CERA, 2010. A review of the environmental safety of the Cry1Ac protein.

[13] Chen, N. C. and Li, H. M. 2000. Vegetable production training manual., Asian Vegetable Research and Development Center, Tainan.

[14] Choudhary, B. 1971. Research on eggplants in India. Food Foundation/IITA/IRAT Seminar on vegetable crops research, Ibadan, Nigeria.

[15] Choudhary, B. and Anothai - Choomsai, M. L. 1970. Indian Journal of Agricultural Science. 40:805-812.

[16] Codex Alimentarius 2003. Guideline for the conduct of food safety assessment of foods derived from recombinant DNA plants. vol CAC/GL 45-2003. Codex Alimentarius Commission, Rome

[17] De Candolle, A. 1886. Origin of Cultivated Plants. 2nd ed., reprinted 1959. New York

[18] EPA. 1988. https:// cfpub.epa.gov/ncea/risk/ recordisplay.cfm? deid= 29777.

[19] Gupta K, JL Karihaloo and RK Khetarpal (2014) Biosafety Regulations for GM Crops in Asia- Pacific. Asia-Pacific Consortium on Agricultural Biotechnology, New Delhi and Asia- Pacific Association of Agricultural Research Institutions, Bangkok, xii+160 p.

[20] Hoffmann, C., Vanderbruggen, H. V., Hofte, H., Van Rie, J., Jansens, S., and Van Mellaert, H. 1988. Specificity of B. thuringiensis deltaendotoxins is correlated with the presence of high affinity binding sites in the brush border membrane of target insect midguts Proc. Natl. Acad. Sci. USA 85:7844-7848.

[21] https://bteggplant.cornell.edu.

[22] https://en.wikipedia.org/wiki/Thorns,_spines,_and_prickles\#Spines.

[23] https://mightybrinjal.files.wordpress.com/2008/09/toxicology-andallergenicity-studiesvol1_.pdf).

[24] http://www.envfor.nic.in/divisions/csurv/geac/bt_brinjal.html.

[25] ISAAA, 2018. https://www.isaaa.org/resources/publications/briefs/54/ executivesummary/default.asp.

[26] Isshiki, S. and N. Kawajiri. 2002. Effect of cytoplasm of Solanum violaceum Ort. on fertility of eggplant (S. melongena L.). Sci. Hort. 93:9-18.

[27] Jung-Il Cho, Sung-Han Park, Gang-Seob Lee, Su-Min Kim, Su-Mi Lim, Youn-Shic Kim, Soo-Chul Park. 2020. Current Status of GM
Crop Development and Commercialization. Korean J. Breed. Sci. 52(S):40-48. https://doi.org/10.9787/KJBS.2020.52.S.40.

[28] Kantharajah AS, Golegaonkar PG (2004). Somatic embryogenesis in eggplant. Sci Hortic-Amsterdam 99(2):107-117. Kashyap V, Kumar SV, Collonnier C, Fusari F, Haicour R, Rotino.

[29] Keck, P.J. and Mitsky, T.A. 1994. Comparative alignment of insecticidally active Bt.k. HD-73 protein (Batik. protein) to known allergenic and toxic proteins using the FASTA algorithm. An unpublished study conducted by Monsanto Company. Monsanto Technical Report. MSL-13643, St. Louis, MO, USA.

[30] Keese P, 2008. Risks from GMOs due to horizontal gene transfer. Environmental Biosafety Research 7:123-149.

[31] Knapp, S., M.S. Vorontsova, and J. Prohens. 2013. Wild relatives of the eggplant (Solanum melongena L.: Solanaceae): New understanding of species names in a complex group. PLoS One 8:e57039.

[32] Knowles, B.H. and dow, J.A.T. 1993. The crystal delta-endotoxins of Bacillus thuringiensis- models for their mechanism of action on the insect gut. BioEssays 15, 469-476.

[33] Korkmaz AI, Akgul H, Sevindik M, Selamoglu Z. 2018. Study on determination of bioactive potentials of certain lichens. Acta Alimentaria, 47(1): 80-87.

[34] Lester, R.N. and J.H. Kang. 1998. Embryo and endosperm failure in Solanum species and hybrids. Ann. Bot. (Lond.) 82:445-453.

[35] Mahyco, 2008. Development of Fruit and Shoot Borer Tolerant Brinjal, Maharashtra Hybrid Seeds Company Ltd., Mumbai.

[36] Martin FW and Rhodes AM. 1979. Subspecifc grouping of eggplant hybrid cultivars. Euphytica 28: 367-383.

[37] Meherunnahar, M., and Paul, D. N. R. 2009. Bt brinjal: introducing genetically modified brinjal (eggplant/aubergine) in Bangladesh. Bangladesh Development Research Working Paper Series BDRWPS No. 9, Bangladesh Development Research Center (BDRC). Available $\quad$ at:
URL: http://www.bangladeshstudies.org/files/WPS_no9.pdf. doi: URL: http://www.bang

[38] Metcalfe, D.D., Astwood, J.D., Townsend, R., Sampson, H.A., Taylor, S.L. and Fuchs, R.L. 1996. Assessment of the allergenic potentials of foods derived from genetically engineered crop plants. Critical Reviews in Food science and Nutrition. 36(S): S165-S186.

[39] Mohamed AE, Rashed MN, Mofty A. 2003. Assessment of essential and toxic elements in some kinds of vegetables. Ecotox Environ Safe 55(3):251-60.

[40] Mondal, R.I., A. K. M Quamruzzaman, K. Hasan, and D. Khanam. 2016. The journey of Bt eggplant in Bangladesh. Proceedings of the 4th Annual South Asia Biosafety Conference, Sept. 19-21, 2016. Hyderabad, India.

[41] National Biosafety Framework 2006. file:///Users/q.zaman/ Downloads/National\%20Biosafety\%20Framework.pdf.

[42] Nielsen KM, AM. Bones, K. Smalla, JDV Elsas. 1998. Horizontal gene transfer from transgenic plants to terrestrial bacteria-a rare event? FEMS Microbiology Reviews 22:79-103.

[43] Perlak, F.J., Deaton, R.W., Armstrong, T.A., Fuchs, R.L., Sims, S.R., Greenplats, L.T., and Fishholl, D.A. 1990. Insect resistant cotton plants. Biotechnology 8:939-943.

[44] Prain, D., 1903. Bengal Plants. Bishen Singh Mahendra Pal Singh, Dehra Dun., pp. 742-753.

[45] Prodhan MZH, Hasan MT, Chowdhury MMI, Alam MS, Rahman ML, Azad AK, et al. 2018. Bt eggplant (Solanum melongena L.) in Bangladesh: Fruit production and control of eggplant fruit and shoot borer (Leucinodes orbonalis Guenee), effects on non-target arthropods and economic returns. PLoS ONE 13(11): e0205713. https://doi.org/10.1371/journal. pone.0205713.

[46] Rahman, S. 2013. Pesticide consumption and productivity and the potential of IPM in Bangladesh. Sci. Total Environ. 445-446, 48-56. doi: $10.1016 /$ j.scitotenv.2012.12.032.

[47] Rao NN. 1979. The barriers to hybridization between Solanum melongena and some other species of Solanum. In: Hawkes JG, Lester RN, Skelding AD (eds) The biology and taxonomy of the Solanaceae. Academic Press, London, pp 605-614.

[48] Ream, J.E. 1994. Assessment of the in vitro digestive fate of Bacillus thuringiensis var. kurstaki HD-73 protein. A study conducted by Monsanto Company, Monsanto Study MSL-13299, St. Louis, MO.

[49] Sambandam, C.N. 1964. An outlook in eggplant breeding. Eco. Bot. 18:128-131.

[50] Sanchez-Castillo CP, Englyst HN, Hudson GJ, Lara JJ, Solano ML, Munguia JL, James WP (1999). The non-starch polysaccharide content of Mexican foods. J Food Compos Anal 12(4):293-314.

[51] Shelton AM, Hossain MJ, Paranjape V, Azad AK, Rahman ML, Khan ASMMR, Prodhan MZH, Rashid MA, Majumder R, Hossain MA, Hussain SS, Huesing JE and McCandless L 2018. Bt Eggplant Project 
in Bangladesh: History, Present Status, and Future Direction. Front. Bioeng. Biotechnol. 6:106. doi: 10.3389/fbioe.2018.00106.

[52] Shelton, A. M., K. E. Hokanson, D. M. Hautea, M. J. Hossain, M.A. Hossain, V. Paranjape, R.A. Hautea, L. McCandless, and S. H. Sarwer. 2017. Bt Eggplant: A Genetically Engineered 'Minor' Crop Comes of Age in Bangladesh and the Philippines. ISB News Report.

[53] Sihachkr D, Chaput M.H, Serraf L, Ducreux G. 1993. Regeneration of plants from protoplasts of eggplant (Solanum melongena L.). In: Bajaj, Y.P.S. (Ed.), Biotech in Agri and Forestry, Plant Protoplasts and Genetic Engineering. Springer, Berlin., 108-122.

[54] Van Rie, J., Jansens, S., Höfte, H., Degheele, D., and Mellaert, H.V. 1990. Receptors on the brush border membrane of the insect midgut as determinants of the specificity of Bacillus thuringiensis deltaendotoxins. Appl. Environ. Microbiol. 56:1378-1385.

[55] Van Rie, J., Jansens, S., Hofte, H., Degheele, D., and Van Mellaert, H. 1989. Specificity of Bacillus thuringiensis endotoxins: importance of specific receptors on the brush border membrane of the mid-gut of target. insects. Eur. J. Biochem. 186:239-247.

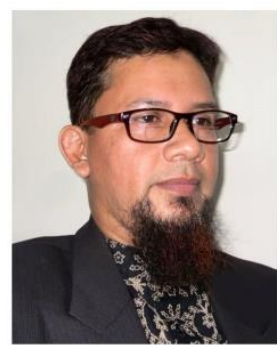

AKM Quamruzzaman is serving as Principal Scientific Officer at Olericulture Division, BARI, Gazipur, Bangladesh. He joined BARI on 1995 as Scientific Officer. As a vegetable scientist, now he is the principal breeder of Solanaceous and Cucurbitaceous vegetables research at BARI.

Dr. Quamruzzaman born in Dhaka, Bangladesh, and got $\mathrm{PhD}$ degree in Horticulture from Bangabandhu Sheikh Mujibur Rahman Agricultural University (BSMRAU) in 2011. He stood 11th position amongst 400 students in BScAg (Hons) from BAU in 1990. He earned MS in Horticulture in 2003 from BAU.

During his 26 years' service length, he developed more than 27 vegetables varieties and published more than 70 scientific articles in renowned local and international journals. He is also serving as Project Investigator of different Government and International organization funded projects viz., FAO, AFACI, WordVeg, NATP, SACP-IFAD.

Dr. Quamruzzaman is an active member of the American Society for Horticultural Science (ASHS), the Japanese Society for Horticultural Science (JSHS), the Bangladesh Society for Horticultural Science (BSHS), Plant Breeding and Genetics Society of Bangladesh (PBGSB), Bangladesh entomological society. 